\title{
Fitting to the job: the role of generic and vocational competenties in adjustment and performance
}

Citation for published version (APA):

Heijke, J. A. M., Meng, C. M., \& Ris, C. J. (2002). Fitting to the job: the role of generic and vocational competenties in adjustment and performance. Researchcentrum voor Onderwijs en Arbeidsmarkt, Faculteit der Economische Wetenschappen. ROA Research Memoranda No. 6E https://doi.org/10.26481/umaror.200206E

Document status and date:

Published: 01/01/2002

DOI:

10.26481/umaror.200206E

Document Version:

Publisher's PDF, also known as Version of record

\section{Please check the document version of this publication:}

- A submitted manuscript is the version of the article upon submission and before peer-review. There can be important differences between the submitted version and the official published version of record. People interested in the research are advised to contact the author for the final version of the publication, or visit the DOI to the publisher's website.

- The final author version and the galley proof are versions of the publication after peer review.

- The final published version features the final layout of the paper including the volume, issue and page numbers.

Link to publication

\footnotetext{
General rights rights.

- You may freely distribute the URL identifying the publication in the public portal. please follow below link for the End User Agreement:

www.umlib.nl/taverne-license

Take down policy

If you believe that this document breaches copyright please contact us at:

repository@maastrichtuniversity.nl

providing details and we will investigate your claim.
}

Copyright and moral rights for the publications made accessible in the public portal are retained by the authors and/or other copyright owners and it is a condition of accessing publications that users recognise and abide by the legal requirements associated with these

- Users may download and print one copy of any publication from the public portal for the purpose of private study or research.

- You may not further distribute the material or use it for any profit-making activity or commercial gain

If the publication is distributed under the terms of Article $25 \mathrm{fa}$ of the Dutch Copyright Act, indicated by the "Taverne" license above, 


\title{
Fitting to the Job: the Role of Generic and Vocational Competencies in Adjustment and Performance*
}

\author{
ROA-RM-2002/6E
}

Hans Heijke, Christoph Meng, Catherine Ris

* We would like to thank Lex Borghans, Harald Schomburg, Bruce Weinberg, Gerard Pfann, the conference participants at ILM (2002, Aberdeen), TIY (2002, Florence), EALE (2002, Paris) and the participants at a ROA seminar (2002, Maastricht) and at ROA's Human Capital Workshop (2002, Maastricht) for comments, suggestions and discussions on earlier drafts of this paper. We acknowledge the Netherland Organization for Scientific Research (NWO) for financial support.

Research Centre for Education and the Labour Market

Faculty of Economics and Business Administration

Maastricht University

Maastricht, December 2002 
ISBN 90-5321-354-6

Sec03.010.doc 


\begin{abstract}
This paper provides new insight into the role of generic and vocational competencies during the transition from education to the labor market. Using data on the labor market situation of Dutch higher education graduates, we analyze the allocation over different educational domains, the incidence of onthe-job training and its impact on wages. The results reveal the different roles of competencies. Vocational competencies influence positively the chance of being matched to an occupation inside the own domain. Generic competencies influence positively both the chance of being matched to an occupation outside the own domain and the training participation.
\end{abstract}





\section{Introduction}

In the transition period from education to the labor market, graduates from different educational backgrounds apply for jobs where they can employ knowledge and skills acquired at school. The process that matches heterogeneous graduates to heterogeneous jobs within this transition period has received much attention in the literature (e.g., Jovanovic, 1979, 1984; Barron and Loewenstein, 1985; Topel, 1986). If this match is not optimal, additional learning by training and job experience is needed to improve or adjust the initial competencies acquired during education. Indeed, the importance of on-the-job training for improving competencies has long been emphasized (Becker, 1964; Mincer, 1974) and there have been many debates on its impact on productivity and wages (Brown, 1989; Lynch, 1992; Acemoglu and Pischke, 1998; Pischke, 2000). Two features with respect to this postponed learning process are of importance.

First, the effectiveness with which graduates are able to adjust or improve their competencies is strongly determined by the level and type of competencies acquired in initial education. The importance of initial education can be found in the discussion on whether on-the-job training and initial education are complements or substitutes. Analyses show evidence of complementarity between education and on-the-job training (Barron, Black and Loewenstein, 1989; Brunello, 2001). Indeed, an implication of the human capital theory is that individuals who learn quickly, that is the ones with the highest level of education, would be more likely to take part in training since they are associated with lower costs for learning. Considering this framework, this paper focuses on the role of 
two types of competencies, namely vocational (field-specific) competencies and generic competencies, defined as a combination of learning abilities, analytical abilities and problem solving abilities. Hence, we build our analyses upon the line of research placing competencies directly at the central stage and discussing in particular what education should provide. Bishop (1995), although not neglecting the role of generic competencies, advocates the educational system to focus on occupation-specific competencies. In line with that, Bishop and Kang (1989), Campbell and Laughlin (1991) and Mane (1998) found stronger positive effects on labor market outcomes for vocational courses than for generic courses. While these authors stress the importance of vocational, and hence occupationspecific competencies, other authors (e.g., Stasz et al., 1993) emphasize the importance of more general academic competencies.

Second, the actual adjustment to be made depends on the outcome of the graduate-job match. Considering the allocation of higher education graduates over jobs, in particular the match between the field of study required and the field of study graduated from influences the required adjustments and the costs involved with these adjustments. Whereas graduates matched to an occupation closely linked to their field of study may need to adjust their level of competencies, graduates matched to an occupation not closely linked to their field of study (misallocation) also have to adjust the type of competencies.

This paper contributes to these discussions by analyzing the role of different human capital competencies in the allocation and adjustment to requirement of the job processes. For that purpose, using features in the cross literature on 
graduate-job matching and on on-the-job training, we develop a simultaneous equations model, in which misallocation and training are analyzed. Using the framework of the misallocation-training model, we furthermore investigate the return to training, the wage difference according to the allocation outcome and the impact of competencies mismatches on earnings. Unlike previous works, our analysis does not rely on general versus firm-specific training but rather on an upstream distinction between generic and vocational competencies acquired by workers. To investigate these issues, we use data from a survey designed to collect detailed information on formal education attained, including information on competencies, additional training followed after graduation, and job requirements. As the data exclusively concern young Dutch graduates interviewed three years after graduation, they allow to analyze the allocation and adjustment processes in the early labor market careers of graduates. The results outline the different roles of generic and vocational competencies for the adjustment to the requirements of the job and the performance in the job, respectively. We find that vocational competencies influence positively the chance of graduates of being matched to an occupation inside the own domain, where these graduates have a comparative advantage. Generic competencies influence positively both the chance of being matched to an occupation outside the own educational domain and the training participation. These results show that the use of generic competencies is not context bound and allows to acquire the newly required competencies. By explicitly introducing the level of initial skills, we show that on-the-job training uses generic competencies to improve vocational 
competencies. Actually, this approach differs from the one followed by the literature that investigates the pay-off of different human capital skills acquired in education by introducing them directly in the wage equation (see for instance, Bishop, 1995). Especially the role of generic skills appears difficult to reveal with this last approach (Heijke, Meng and Ramaekers, 2002). By developing a model in different steps, our approach reveals the specific role of generic and vocational competencies.

This empirical paper is structured as follows. Section 2 discusses the impact of generic and vocational competencies on the allocation outcome, on the on-the-job training incidence and on productivity, achieved in a particular occupation. Section 3 presents the data used in this paper. The econometric model is developed in section 4. Firstly, a bivariate probit is estimated to evaluate the impact of both types of competencies on the allocation process and training incidence. Secondly, the influence of vocational competencies mismatches and training on wages is investigated. Section 5 contains concluding remarks.

\section{Allocation and on-the-job training}

\subsection{Generic versus vocational competencies}

Higher education is organized around disciplines or higher professional fields and hence around the learning of discipline or field specific (vocational) competencies. However, in higher education students acquire not only vocational knowledge and skills but also generic competencies. Generic competencies can 
be defined as a combination of competencies providing a strong basis for further learning. This indicates that the term generic competencies includes more than just learning abilities in a strict sense, and can also include problem-solving or analytical competencies. Consequently, we start by assuming that the human capital endowments of a higher education graduate $i$ at time $t=0$ (time of graduation) is a combination of vocational competencies $\left(V_{i, s, 0}\right)$ of a particular field $(s)$ and generic competencies $\left(G_{i, 0}\right)$

$$
H C_{i, t=0}=f\left(V_{i, s, 0}, G_{i, 0}\right)
$$

To facilitate the analysis, we take the level of competencies possessed at the time of graduation as given, forgoing thereby the discussion on the precise process of competencies acquisition in higher education. Furthermore, we assume vocational competencies as variable throughout the time period under consideration. Hence, the level of vocational competencies possessed at time of graduation is only a starting level and increasing it is possible through additional training or simply through work experience. Generic competencies are seen as transferable between different kinds of occupations or different educational domains. Hence, and in contrast to vocational competencies, that are characterized by a vertical dimension and a horizontal (e.g. medicine versus business) dimension, generic competencies are only characterized by a vertical (low versus high) dimension. In this sense, it is irrelevant in which educational program (e.g. medicine or business) they are acquired. 


\subsection{Allocation and on-the-job training determinants}

During the transition period from higher education to the labor market, heterogeneous graduates, characterized by their specific mix of competencies, are allocated to heterogeneous occupations. As in the case of the graduates, we assume that occupations are in particular characterized by the competencies required. More precisely, occupations are characterized by a required type of vocational competencies and a required level of vocational competencies. Considering the allocation process of graduates over occupations, we therefore have to deal with two different adjustment dimensions. On the one hand, the horizontal dimension, which indicates that graduates can be matched to occupations outside their own educational domain (e.g. an engineering graduate is matched to a foreign exchange trading occupation). On the other hand, we have to deal with the vertical dimension, indicating a gap between the acquired level and the required level of the same type of vocational competencies. According to the assignment theory (e.g., Sattinger, 1993), the productivity outcome of a particular graduate-occupation match is determined by the relation between the type and level of competencies required in the occupation and the type and level of competencies acquired by the graduate. In other words, if the graduates' endowment with respect to the level and type of vocational competencies does not match perfectly the requirements of the occupation, and hence if a vocational competencies mismatch exists that negatively influences productivity, employees need to invest further in the acquisition of vocational competencies (van Eijs and Heijke, 2000). 
The amount of on-the-job training needed is therefore positively related to the actual vocational competencies mismatches. Furthermore, we can expect the return to on-the-job training, measured in terms of a reduction in the vocational competencies mismatch, to be determined by the quality of the graduate as a learner and hence by the graduate's level of competencies. This is in line with research indicating that more educated workers train more because the available human capital is an input in the production of new human capital or because workers who are better learners invest more in both schooling and training (Bartel and Sicherman, 1998; van Smoorenburg and van der Velden, 2000; Stasz, 2001). The distinction between generic and vocational competencies made in this paper allows to identify the specific role of the initial level of these two kinds of human capital competencies in the allocation and in training participation.

\section{The data}

The data used in this paper are obtained from a postal survey among 1994/1995 Dutch higher education graduates. Since the survey was held some three years after graduation (in 1998), the study observes graduates at the beginning of their professional careers. In the Netherlands, a division can be made between university education (WO) and higher vocational education (HBO). Universities provide academic education and intend to provide their graduates with scientific knowledge in a particular field or discipline. Higher vocational education institutes, on the other hand, provide higher professional education and intend 
to provide their graduates with knowledge that is directly linked to a particular occupation.

In total, 3087 Dutch graduates responded to this survey ${ }^{1}$. All respondents covered in this paper completed degree courses. Table 1 shows that a small majority of the respondents is female and that the graduates are on average 29 years old at the time of the survey. $58 \%$ of the respondents graduated from higher vocational education. At the time of the survey, $84 \%$ of them have a full-time position and $79 \%$ have a permanent contract. Apart from their formal qualification, $67 \%$ of the graduates have gained additional qualifications by participating in training in the first 3 years after graduation ${ }^{2}$.

\section{Insert Table 1.}

The data also contains information with respect to 36 different competencies representing demands for and supplies of knowledge. Graduates were asked to indicate on a 5-point scale, ranging from 1 ('not at all') to 5 ('to a very high extent'), the extent to which they had a given competency at time of gradation (in 1994 or 1995) (the acquired level of competency) and the extent to which this given competency is required in their current work (the required level of competency). Using a hierarchical clustering $\operatorname{method}^{3}$, we retain two clusters of competencies representing best our idea of generic competencies and vocational competencies. The two clusters consist of the following individual items:

\footnotetext{
${ }^{1}$ However, this paper covers fewer than 2000 graduates because only graduates for whom data on the variables used are available are included.

${ }^{2}$ In order to take into account all kinds of further education and training which can improve the graduates' competencies, the variable training is equal to one if the graduate reported 'having undertaken further education and training since graduation'.

${ }^{3}$ See Appendix 1 for details of the hierarchical clustering method.
} 


\section{Generic competencies}

- Learning abilities

- Reflective thinking, assessing one's own work

- Problem solving abilities

- Analytical competencies

- Documenting ideas and information

2. Vocational competencies

- Field-specific theoretical knowledge

- Field-specific knowledge of methods

The internal consistency of the two clusters is supported by Cronbach's alphas of 0.76 . For our analysis, an average of the competency clusters possessed at the time of graduation and of the competency clusters required in the current job was calculated for each individual.

In addition to the actual level of vocational competencies possessed at the time of graduation, the analysis focuses on the distances between the required and the acquired level or type of vocational competencies. The vertical vocational competencies mismatch (mismatch in level) is measured by subtracting the acquired level of vocational competencies from the required one. The horizontal vocational competencies mismatch (mismatch in type), and hence the misallocation, is measured by another question in the survey concerning the relationship between the graduate's field of study and his or her area of work. A horizontal mismatch occurs if the graduate reported that neither 'the own field of study' nor 'a related field of study 'would have been the best prepara- 
tion . In our sample, $18 \%$ of graduates reported having a job outside their own educational domain.

\section{A model for misallocation, training and ear-}

\section{nings}

To evaluate the impact of having a job not closely linked to one's own educational domain (misallocation) and the impact of training, running a simple OLS regression of the wages on the characteristics of graduates and firms and on dummies for misallocation and training cannot deal with selection issues. Indeed, the allocation process of graduates over jobs inside and outside their own educational domain and participation in training, as noted by Goux and Maurin (2000), obviously rely on both graduates' observed and unobserved abilities. Consequently, the estimated effects of misallocation and training on wages could be biased because the unobserved abilities determine wage, allocation and training simultaneously. Moreover, the impact of misallocation on wages is undoubtedly different for trained and non-trained employees. As for the former group, the effect of misallocation can be weak, as training is used to reduce the initial mismatch; as for the latter group, the impact of misallocation can still be negative. Participation in training should then be analyzed as a determinant of the misallocation impact on wages. To take this into account, not only the training variable but also the misallocation-training interaction variable should be analyzed as wage determinants. In the case that graduates are also likely 
to be selected for training depending on their (mis)allocation, we may further expect to find a correlation between training and (mis)allocation. In order to deal with these two selectivity criteria, we develop a wage model with two selection functions, one for (mis)allocation and one for training. This allows us not only to identify the allocation process of graduates and the training-selection mechanism of employees but also the impact of competencies mismatches on wages.

\subsection{Misallocation and training selection}

Let $H M M_{i j}$ be the dummy that denotes that graduate $i$ is assigned to a job $j$ not matching his type of vocational competencies ${ }^{4}, T P_{i j}$ is the dummy that denotes that graduate $i$ takes part in further training while holding job $j$, and $\ln w_{i j}$ is the logarithm of wages.

We consider the following system of simultaneous equations

$$
\begin{aligned}
H M M_{i j}^{*} & =\gamma_{1} \mathbf{W}_{i j}+\epsilon_{1 i j} \\
H M M_{i j} & =1 \text { if } H M M_{i j}^{*}>0 \text { and } H M M_{i j}=0 \text { otherwise } \\
T P_{i j}^{*} & =\delta_{1} \mathbf{Z}_{i j}+\delta_{2} H M M_{i j}+\epsilon_{2 i j} \\
T P_{i j} & =1 \text { if } T P_{i j}^{*}>0 \text { and } T P_{i j}=0 \text { otherwise } \\
\ln w_{i j} & =\tau_{1} \mathbf{x}_{i j}+\tau_{2} H M M_{i j}+T P_{i j}\left(\tau_{3} H M M_{i j}+\tau_{4}\right)+u_{i j}
\end{aligned}
$$

where $\mathbf{W}_{i j}$ is a vector of independent variables that influences the allocation

\footnotetext{
${ }^{4}$ See definition of the horizontal mismatch in section 3 .
} 
over jobs, such as individual and education characteristics, $\mathbf{Z}_{i j}$ is a vector of independent variables that influences participation in training. As discussed above, determinants of training may include measures of mismatches but also the acquired level of competencies in addition to other individual characteristics. $\mathbf{X}_{i j}$ is a vector of individual and firm characteristics that determines wages. Coefficient $\tau_{2}$ allows to identify the impact of misallocation on wages. $\tau_{3}$ captures the difference between the impact of misallocation for trained and non-trained graduates.

To take endogeneities with respect to the (mis)allocation and the training process into account, we assume $\epsilon_{1 i j}, \epsilon_{2 i j}$ and $u_{i j}$ to be correlated and normally distributed. Consequently, we use an extension from the two-step treatment effect method discussed by Barnow, Cain and Goldberger (1981), derived from Heckman (1976) and Maddala and Lee (1976). Firstly, we estimate the allocation process and training participation using a bivariate probit model. Secondly, we estimate the wage equation and add $\lambda_{1 i j}=E\left(\epsilon_{1 i j} / H M M_{i j}, T P_{i j}\right)$ and $\lambda_{2 i j}=E\left(\epsilon_{2 i j} / H M M_{i j}, T P_{i j}\right)$ as additional independent variables to control for selectivity. These ratios are provided by the estimation of the bivariate probit.

To assure identification of the parameters, we need variables that can be expected to be correlated with misallocation and training but not with the unobserved determinants of wages. First, in both the misallocation and the training function, we use the level of generic competencies as reported at time of graduation and the level of vocational competencies as reported at time of 
graduation. The assumption here is that graduates undoubtedly increase their initial level of competencies through additional training or work experience during their first years in the labor market. So the levels of these competencies, reported as possessed at the time of graduation, characterize the graduates' performance three years before wages are reported. It is assumed that these levels are not correlated with the unobservable in the wage equation because the levels have changed since graduation, and because we can obviously expect that the increase differs between graduates. Initial levels of competencies determine the allocation process and training participation, both of which determine the way competencies will change. By developing a model in different steps, our approach reveals more precisely the specific role of generic and vocational competencies $^{5}$. Furthermore, we include variables describing the graduate's home situation as specific determinants of training and misallocation. Living with a partner or parents can relax the graduates financial constraints and allow him or her to search longer for a good match. On the other side, having children (in particular for female graduates) may restrict graduates with respect to the time available for investment in further training. Moreover, as regressors for the misallocation function, we use a vector of variables that influences $H M M$ but not $T P$, such as the importance given to the possibilities of using knowledge and skills acquired in higher education, and the extent to which graduates reported that they possessed adaptability as a competence at the time of graduation ${ }^{6}$.

\footnotetext{
${ }^{5}$ Introducing the initial levels of competencies in the wage equation does not provide a significant impact of them and does not change the outcome for other variables (data not shown in this paper).

${ }^{6}$ For these two last variables, graduates were asked to indicate on a 5-point scale, ranging
} 
To identify the training effect, we also use the number of firms offering training courses for firms in the region in which the graduates works. An increased supply of training courses in the region may increase the training opportunities for firms and enable more employees to participate in training.

\section{Insert Table 2.}

Table 2 presents the results of the bivariate probit analysis. Turning first to the misallocation estimation, the results clearly indicate the importance of the two distinguished competencies for the probability of a mismatch. A higher level of vocational competencies decreases the probability of being matched to an occupation outside one's own educational domain, which confirms the fieldlimited usefulness of vocational competencies. In contrast to this finding, a higher level of generic competencies increases the chance to obtain a job outside one's own educational domain, indicating that generic competencies are not context bound. As generic competencies are defined as a combination of learning abilities, analytical abilities and problem solving abilities, they provide skills to deal with new problems in a large range of domains and are in particular needed outside the domain to learn the newly required competencies. Furthermore, we see that graduates with study-related working experience during their study time have a higher probability of finding an occupation inside their own educational domain, which indicates that the investment made by establishing contact with employers inside their own educational domain helps

from 1 ('not at all') to 5 ('to a very high extent') their answer. 
them in the job search. With respect to the field of study, graduates from law, natural sciences and health have an increased probability to find an occupation inside the own educational domain. As discussed above, we further included the home situation, the importance given to the use of the acquired skills and the acquired level of adaptability competency as instrumental variables. The latter two seem to be important factors. The importance given to the use of acquired skills positively influences the probability to be matched to an occupation inside the own educational domain. Having a high level of adaptability, on the other hand, positively influences the probability of being matched to an occupation outside the own educational domain.

We turn now to the results concerning the training incidence. We see that the level of generic competencies, as possessed at the time of graduation, has a significant and positive influence on training participation. On the other hand, the level of vocational competencies seems to have no impact on training incidence. These results indicate that complementarity between initial education and training can be established, but only for a certain kind of initial skills, namely generic competencies. This is in line with the idea that generic competencies acquired in higher education reduce the costs of further learning by providing higher learning abilities for graduates. As introduced in the previous section, we might expect competencies mismatches to be costly because of the productivity lost due to them. In this sense, the amount of on-the-job training needed is expected to be positively related to the actual vocational competencies mismatches, as training is needed to adjust the acquired competencies to 
the required ones. Results show that the horizontal mismatch resulting from being matched to an occupation outside one's own educational domain has no additional impact on participation in training. This result indicates that graduates who are matched to an occupation inside their own educational domain are as likely to be trained as graduates who are matched to an occupation outside their own educational domain ${ }^{7}$. In addition to this horizontal mismatch, graduates may also face a vertical vocational competencies mismatch. The results indicate that an increase in the level of vertical vocational competencies mismatch for graduates inside their own educational domain does not significantly increase training participation. This may indicate that graduates, if matched to an occupation closely linked to their field of study, benefit from a suitable work environment to close an existing vocational competencies mismatch partially by learning-by-doing. Contrary to this finding, we see that for graduates matched to an occupation outside their own educational domain, an increasing vertical vocational competencies mismatch has a positive influence on training participation. This result shows that when the match between field of study and occupation is not optimal, graduates do not benefit from such a work environment and obviously have to reduce an existing vertical vocational competencies mismatch by formal training. We also introduce a measurement for the educational level match between the graduates and their job. Neither in the case of undereducation nor in the case of overeducation is there a significant change in the training incidence. Overeducated graduates, whose learning capacities are

\footnotetext{
${ }^{7}$ However, it has to be recalled that graduates who experience a horizontal mismatch have a higher level of generic competencies which influences their participation in training positively.
} 
already explicitly taken into account by their level of generic competencies, do not need to follow formal training. For undereducated graduates, training is not provided by firms to substitute for a missing educational level. Moreover, female graduates with children are less likely to participate in training. Finally, the number of firms offering training courses in the province in which the graduate works has a positive influence on the chance to participate in training.

\subsection{Mismatches' effects on wages}

We now turn to the discussion with respect to the wage estimation results, controlling for the results found in the previous estimations. Results are reported in Table 3.

\section{Insert Table 3}

First of all, the results show that graduates matched to an occupation outside their own educational domain have significantly lower wages, which indicates that graduates matched to an occupation inside their educational domain benefit from a comparative advantage. With respect to the training incidence variable, we find that participation in training has a positive and significant impact on wages ${ }^{8}$. Dutch higher education graduates following on-the-job training in the three first years after graduation, see their wages increase by approximately $6 \%$. However, no difference is found between the return to training for graduates working inside their own educational domain and the return to train-

\footnotetext{
${ }^{8}$ Note that the significant and positive sign of $\lambda_{2}$ indicates that there are unobserved factors influencing positively the training incidence and the wage rate.
} 
ing for graduates working outside their own educational domain. Moreover, to evaluate the impact of an additional vertical mismatch, we introduce, as in the training function, an interaction variable between the vertical vocational competencies mismatch and the horizontal vocational competencies mismatch. Graduates working outside their own educational domain already suffer from a wage penalty (due to their horizontal vocational skills mismatch), and it seems that having an additional vertical mismatch has no more impact on their wages, in particular if they followed training to reduce their mismatch (as these graduates have higher training participation rates). We find that graduates working inside their own educational domain see their wages decrease significantly as their vertical mismatch increases. Consequently, an initial lack of the vocational competencies acquired in higher education reduces productivity only if the graduates are matched to an occupation inside their own educational domain.

The wage equation also allows to evaluate the return to learning-by-doing (measured by the job tenure in months). The results show that already in the graduates' early careers, learning-by-doing and hence prolonged working experience, has a significant impact on wages ${ }^{9}$. No difference is found with respect to the return to tenure inside and outside one's own educational domain. We also evaluate the impact of an educational level mismatch on wages. Following previous studies (Sicherman, 1991; Cohn and Kahn, 1995; Hartog, 2000), we find that wages are not only determined by individual characteristics but also

\footnotetext{
${ }^{9}$ No evidence was found of decreasing returns of tenure. The reason is probably that the survey only enable us to observe a maximum of 3 years tenure.
} 
by job level. Overeducated graduates receive lower returns than similar graduates having a job that matches their educational level. On the other hand, undereducated graduates get more than similar graduates having a matching job $^{10}$. As noted by Allen and van der Velden (2001), 'although higher education raises productivity in general, the actual level of productivity realized is also determined by the match between educational level and job level'. As for example, working in a job below one's own level imposes a limitation on the utilization of skills, the lower level of the job imposes a ceiling on the worker's productivity, resulting in lower wages.

The wage equation also controls for some other individual and firm characteristics. The results are thereby standard and hence need not be discussed any further.

\section{Conclusion}

This study contributes to the discussion on the roles of vocational and generic competencies during the transition from higher education to the labor market. These competencies are primary determinants of the allocation process and training participation; they do not influence the wage directly but only through their impact in earlier stages of the young graduate's career. More in particular, the level of generic competencies determines - on the one hand

\footnotetext{
${ }^{10}$ Our results are closed to those reported by Cohn and Kahn (1995) for overeducated graduates, who earn $11 \%$ less than similar graduates who work in an occupation for which they are adequately educated. However, for undereducated graduates, our results are lower than those from Cohn and Kahn (1995) (3.8\% compare to 10 to $14 \%$ ).
} 
- both the allocation outside the own domain and training participation. This result confirms that generic competencies are not context bound and provide abilities that are useful in a wide range of domains as well as learning abilities that are useful to acquire the newly required competencies. On the other hand, the level of vocational competencies influences positively the chance of graduates of being matched to an occupation inside one's own educational domain, where these graduates have a comparative advantage. Furthermore, the wage analysis shows that an initial vocational competencies mismatch, either due to a lack in the level of vocational competencies acquired or due to a mismatch in the type of vocational competencies acquired, reduces the productivity of the graduate-occupation match.

Contributing to the empirical literature that investigates whether training and education are complements or substitutes, we show that the quality of education needs to be taken into account. Indeed, training and the level of generic competencies acquired in education are found to be complements, but no significant relationship is established between the level of vocational competencies and training. Actually, on-the-job training uses generic competencies to adjust vocational competencies to the requirement of the job. 
Appendix 1. Generic and vocational competencies clusters.

From the 36 different competencies available in the data we use in this paper only competencies describing the nest of generic competencies and vocational competencies. Using Ward's hierarchical method for cluster analysis, we formed groups of competencies according to the level required in the current occupation. This method optimizes the minimum variance within clusters. The algorithm begins with one large cluster encompassing all objects to be clustered and then searches objects that can be grouped together while minimizing the increase in the sum of residuals squared. The hierarchical cluster analysis produced in a first step eight different clusters. Two of these eight clusters correspond to our definition of generic and vocational competencies. To test further for the internal consistency of these two clusters, we calculated the Cronbach alpha which indicates how well a set of items measures a single uni-dimensional construct. Cronbach alpha can thereby be written as a function of the number of items tested (e.g. number of competencies in one cluster) $(N)$ and the average interitem correlation $(r): \alpha=\frac{N \times r)}{1+(N-1) \times r}$. Usually, values of Cronbach alphas above 0.7 are acceptable as indication of internal consistency (Nunnually, 1978). 


\section{References}

Acemoglu, D. and J.-S. Pischke, 1998, Why do firms train? Theory and evidence, The Quarterly Journal of Economics, 113 (1), 79-119.

Allen, J., Velden R. van der, 2000, Educational mismatches versus skill mismatches: effects on wages, job satisfaction, and on-the-job search, Oxford Economic Papers, 53 (3), 434-452

Barnow, B., Cain, G., Goldberger, A., 1981, Issues in the analysis of selectivity bias, in: Stromsdorfer, E., Farkas, G., eds., Evaluation Studies Review Annual, 5 (Sage Publications, Beverly Hills) 43-59.

Barron, J. M., D. A. Black and M. A. Loewenstein, 1989, Job matching and on the job training, Journal of Labor Economics, 7 (1), 1-19.

Barron, J. M. and M. A. Loewenstein, 1985, On employer specific information and internal labor markets, Southern Economic Journal, 52, 431-445.

Bartel, A.P. and N. Sicherman, 1998, Technological change and the skill acquisition of young workers, Journal of Labor Economics, 16 (4), 718-755.

Becker, G.S., 1964, Human capital: a theoretical and empirical analysis with special reference to education (NBER, New York).

Bishop, J.H., 1995, Vocational education and at-risk youth in the United States, Vocational Training European Journal, 6, 34-42.

Bishop, J.H. and N. Kang, 1989, Vocational and academic education in high school: Complements or substitutes? Economics of Education Review, 8(2),133148.

Brown, J., 1989, Why do wages increase with tenure? On the job training 
and life cycle wage growth observed within firms, American Economic Review, 79, 971-991.

Brunello, G., 2001, On the complementary between education and training in Europe, IZA Discussion paper No. 309 (IZA, Bonn).

Campbell, P.B, Laughlin, S., 1991, Participation in vocational education: An overview of patterns and their outcomes (National Centre for Research in Vocational Education, Columbus,).

Cohn, E. and S. P. Kahn, 1995, The wage effects of overschooling revisited, Labour Economics, 2, 67-76

Eijs, P van., Heijke, H., 2000, Mismatch between occupation and education and the costs and benefits of job related training, in: Heijke, $\mathrm{H}$ and Muysken, J., eds., Education and training in a knowledge-based economy (MacMillan Press LTD) $159-189$.

Goux, D. and E. Maurin, 2000, Returns to firm provided training: evidence from French worker-firm matched data, Labor Economics, 7, 1-19.

Greene, W. H., 2000, Econometric Analysis, Fourth Edition (Prentice Hall, New Jersey.).

Hartog, J., 2000, Over-education and earnings: where are we, where should we go?, Economics of Education Review, 19, 131-147.

Heckman, J., 1976, The common structure of statistical models of truncation, sample selection, and limited dependant variables and a simple estimator for such models, Annals of Economic and Social Measurement, 5, 475-492.

Heijke, H., Meng, C., Ramaekers, G., 2000, An investigation into the role of 
human capital competencies and their pay-off, Research Memorandum, ROARM- 2002/3E (Research Centre for Education and the Labour Market, Maastricht).

Jovanovic, B., 1979, Job matching and the theory of turnover, Journal of Political Economy, 87, 1246-1260.

Jovanovic, B., 1984, Matching, turnover and unemployment, Journal of Political Economy, 92,108-122.

Lynch, L., 1992, Private sector training and earnings of young workers, American Economic Review, 82, 299-312.

Maddala, G. S., and L. Lee, 1976, Recursive models with qualitative endogenous variables, Annals of Economic and Social Measurement, 5, 525-545.

Mane, F., 1998, Trends in the payoff to academic and occupation-specific competencies: The short and medium run returns to academic and vocational high school courses for non-college-bound students, Economics of Education Review, 18, 417-437.

Mincer, J., 1974, Schooling, Experience and Earnings (Columbia Univ. Press, New York).

Murphy, K., and R., Topel, 1985, Estimation and inference in two step econometric models, Journal of Business and Economic Statistics, 3, 370-379.

Nunnually, J.C., 1978, Psychometric theory, 2nd edition (McGraw-Hill, New York).

Pischke, J.-S., 2000, Continuous training in Germany, IZA Discussion paper no. 137 (IZA, Bonn). 
Sattinger, M., 1993, Assignment models of the distribution of earnings, Journal of Economic Literature, 31, 831-880.

Sicherman, N., 1991, "Overschooling" in the labor market, Journal of Labor economics, 9 (2), 101-122.

Smoorenburg, M.S.M.van, Velden R van der., 2000, The training of schoolleavers, complementarity or substitution?, Economics of Education Review, 19, 207-217.

Stasz, C., 2001, Assessing skills for work: two perspectives, Oxford Economic Papers, 53, 385-405.

Stasz, C., Ramsey K., Eden R., DaVanzo J., Farris H. and M. Lewis, 1993, Classrooms that work: teaching generic skills in academic and vocational Settings, MR-169-NCRVE/UCB (RAND, Santa Monica, Ca).

Topel, R., 1986, Job mobility, search and earnings growth, Research in Labor Economics, 8, 199-233. 
Table 1. Characteristics of graduates.

\begin{tabular}{lcc}
\hline \hline & mean & std. dev. \\
\hline Gender: Woman & 0.54 & 0.50 \\
Age at time of survey & 28.88 & 2.30 \\
HBO graduates & 0.58 & 0.49 \\
Full-time job & 0.84 & 0.36 \\
Permanent job & 0.79 & 0.41 \\
Further training followed after graduation & 0.67 & 0.47 \\
Level of generic competencies acquired in higher education & 3.61 & 0.55 \\
Level of vocational competencies acquired in higher education & 3.69 & 0.77 \\
Working outside one's own educational domain & 0.18 & 0.38 \\
Tenure (in months) & 31.89 & 21.02 \\
Firm size & 6715 & 25401 \\
Working for a private employer & 0.54 & 0.50 \\
\hline \hline
\end{tabular}


Table 2. Bivariate probit analysis.

\begin{tabular}{|c|c|c|}
\hline Independent variables & Coefficient & std. error \\
\hline \multicolumn{3}{|c|}{ Dependent variable: Working outside own domain $\left(H M M_{i j}\right)$} \\
\hline \multicolumn{3}{|l|}{ Competencies } \\
\hline - Generic competencies obtained & 0.373 & $0.078^{* * *}$ \\
\hline - Vocational competencies obtained & -0.222 & $0.048^{* * *}$ \\
\hline \multicolumn{3}{|l|}{ Experience during studies } \\
\hline - Internship (1-6 months) & 0.107 & $0.101^{* * *}$ \\
\hline - Internship (> 6 months) & -0.027 & $0.097^{* *}$ \\
\hline - Empl. related to study (1-6 months) & -0.317 & 0.122 \\
\hline - Empl. related to study ( $>6$ months) & -0.263 & 0.135 \\
\hline \multicolumn{3}{|l|}{ Field of study graduated from } \\
\hline - Arts and humanities & ref. & \\
\hline - Social sciences & -0.049 & 0.139 \\
\hline - Business & -0.188 & $0.114^{*}$ \\
\hline - Law & -0.878 & $0.209^{* * *}$ \\
\hline - Natural sciences & -0.765 & $0.193^{* * *}$ \\
\hline - Engineering & -0.337 & $0.134^{* *}$ \\
\hline - Health & -0.707 & $0.149^{* * *}$ \\
\hline
\end{tabular}


Table 2 continued

\begin{tabular}{|c|c|c|}
\hline Independent variables & Coefficient & std. error \\
\hline HBO graduate & -0.015 & 0.093 \\
\hline Age & 0.042 & $0.018^{* *}$ \\
\hline Gender: man & -0.110 & 0.080 \\
\hline Living as single & ref. & \\
\hline Living with partner & -0.156 & $0.097^{*}$ \\
\hline Living with parents & -0.171 & 0.108 \\
\hline Living with other persons & -0.106 & 0.104 \\
\hline Importance given to usage of skills & -0.281 & $0.057^{* * *}$ \\
\hline Adaptability & 0.109 & $0.051^{* *}$ \\
\hline Intercept & -1.290 & $0.643^{* *}$ \\
\hline \multicolumn{3}{|l|}{ Dependent variable: Training participation $\left(T R_{i j}\right)$} \\
\hline \multicolumn{3}{|l|}{ Competencies } \\
\hline - Generic competencies obtained & 0.128 & $0.066^{* *}$ \\
\hline - Vocational competencies obtained & -0.028 & 0.062 \\
\hline \multicolumn{3}{|l|}{ Competencies mismatches } \\
\hline - Working outside own domain $\left(H M M_{i j}\right)$ & -0.372 & 0.347 \\
\hline - $H M M_{i j} \times$ vertical vocational mismatch $\left(V M M_{i j}\right)$ & 0.093 & $0.055^{*}$ \\
\hline
\end{tabular}


Table 2 continued

\begin{tabular}{lll}
\hline \hline Independent variables & Coefficient & std. error \\
\hline - Working inside own domain $\times V M M_{i j}$ & 0.016 & 0.042 \\
Educational level mismatch & \multicolumn{2}{l}{} \\
- Same educational level required & ref. \\
- Higher educational level required & -0.117 & 0.101 \\
- Lower educational level required & -0.072 & 0.097 \\
Gender: man & -0.028 & 0.072 \\
Mother & -0.375 & $0.226^{*}$ \\
Age & -0.016 & 0.016 \\
Firm size & $0.25 \mathrm{E}-05$ & $0.14 \mathrm{E}-05^{*}$ \\
Private employer & -0.029 & -0.077 \\
Full-time job & 0.092 & 0.097 \\
Permanent job & 0.245 & $0.077^{* * *}$ \\
Number of firms offering training courses & $0.21 \mathrm{E}-03$ & $0.12 \mathrm{E}-03^{*}$ \\
Intercept & -0.873 & 0.803 \\
\hline Correlation (Misallocation and Training) & 0.344 & $0.187^{*}$ \\
Number of observations & & 1778 \\
Log-likelihood & -1839.89 \\
\hline
\end{tabular}

Notes: the estimation for the training incidence also includes dummies for 16 economic sectors; ${ }^{* * *}$ :significant at $1 \%$ level, ${ }^{* *}$ : significant at $5 \%$ level, ${ }^{*}$ : significant at $10 \%$ level. 
Table 3 . The wage equation.

\begin{tabular}{|c|c|c|}
\hline Independent variables & Coefficients & st.error \\
\hline Working outside own educational domain $\left(H M M_{i j}\right)$ & -0.110 & $0.045^{* * *}$ \\
\hline Training participation $\left(T R_{i j}\right)$ & 0.059 & $0.017^{* * *}$ \\
\hline$T R_{i j} \times H M M_{i j}$ & 0.035 & 0.031 \\
\hline$H M M_{i j} \times$ vertical vocational mismatch $\left(V M M_{i j}\right)$ & 0.003 & 0.007 \\
\hline Working inside own educational domain $\times V M M_{i j}$ & -0.014 & $0.005^{* * *}$ \\
\hline Tenure (in months) & 0.002 & $0.0001^{* * *}$ \\
\hline$H M M_{i j} \times$ Tenure & 0.001 & 0.001 \\
\hline \multicolumn{3}{|l|}{ Educational level mismatch } \\
\hline - Same educational level required & ref. & \\
\hline - Higher educational level required & 0.038 & $0.017^{* *}$ \\
\hline - Lower educational level required & -0.110 & $0.015^{* * *}$ \\
\hline \multicolumn{3}{|l|}{ Experience during studies } \\
\hline Internship during study (1-6 months) & -0.001 & 0.013 \\
\hline Internship during study ( $>6$ months) & 0.008 & 0.013 \\
\hline Empl.related to study (1-6 months) & 0.019 & 0.014 \\
\hline Empl.related to study ( $>6$ months) & 0.065 & $0.017^{* * *}$ \\
\hline
\end{tabular}


Table 3. continued.

\begin{tabular}{lll}
\hline \hline Independent variables & Coefficients & st.error \\
\hline Age & 0.011 & $0.002^{* * *}$ \\
Gender: Man & 0.016 & 0.011 \\
HBO graduate & -0.102 & $0.013^{* * *}$ \\
Permanent job & 0.062 & $0.013^{* * *}$ \\
Full-time job & -0.053 & $0.015^{* * *}$ \\
Private employer & 0.004 & 0.012 \\
Firm size & $0.48 \mathrm{E}-06$ & $0.19 \mathrm{E}-06^{* * *}$ \\
$\lambda_{1}$ (misallocation) & 0.022 & 0.024 \\
$\lambda_{2}$ (training) & 0.047 & $0.027^{*}$ \\
Intercept & 1.904 & $0.503^{* * *}$ \\
\hline Number of observations & & 1778 \\
adjust. $R^{2}$ & & 0.285 \\
F-stat & & 14.37 \\
\hline \hline
\end{tabular}

Notes: dependent variable : log hourly wages are measured based on the reported gross monthly wage rate and the reported working hours as set in the contract (hourly wages are measured as gross wages); the estimation also includes 9 dummies for degrees achieved, 6 dummies for job titles and 16 dummies for economic sectors; ${ }^{* * *}$ : significant at $1 \%$ level, **: significant at $5 \%$ level, ${ }^{*}:$ significant at $10 \%$ level; to estimate $\lambda_{1}$ and $\lambda_{2}$, we use the probit model presented in table 2, standard errors have been adjusted using the Murphy and Topel (1985) correction (the selection model estimation was conducted under LIMDEP 7.0; see Greene, 2000). 